\title{
Recurrent refractory Kawasaki disease
}

\author{
P Costa Reis ${ }^{1,2^{*}}$, S Nativ ${ }^{2}$, A Starr ${ }^{2}$, L Imundo ${ }^{2}$, A Eichenfield ${ }^{2}$ \\ From 18th Pediatric Rheumatology European Society (PReS) Congress \\ Bruges, Belgium. 14-18 September 2011
}

\section{Background}

Kawasaki disease is a common childhood vasculitis. Unrelenting fever after treatment with intravenous immunoglobulin (IVIG) occurs in $10-15 \%$ of patients and is associated with a greater risk of developing coronary aneurysms.

\section{Aim}

Describe a very unique case of recurrent and refractory Kawasaki disease.

\section{Case report}

A 3 year old boy presented with 3 days of fever, rash, pharyngeal and gingival erythema, and swollen extremities. Laboratory investigations revealed leukocytosis, Creactive protein $25.8 \mathrm{mg} / \mathrm{dl}$, and erythrocyte sedimentation rate $100 \mathrm{~mm} / \mathrm{hr}$. Echocardiography disclosed diffuse dilatation of all proximal coronary arteries. The child received IVIG $(2 \mathrm{~g} / \mathrm{kg})$ and aspirin $(100 \mathrm{mg} / \mathrm{kg} / \mathrm{d})$ with no response. IVIG was repeated, followed by methylprednisolone $30 \mathrm{mg} / \mathrm{kg}$ for 3 days, but the child remained febrile. Infliximab $(5 \mathrm{mg} / \mathrm{kg}$ ) was thereupon employed with prompt defervescence. Low-dose aspirin was continued, as well as clopidogrel. Echocardiographic findings remained stable.

Six months after the initial episode, the child again presented with fever, irritability, sore throat and nuchal rigidity. Physical examination revealed cracked, swollen lips, oropharyngeal erythema, posterior cervical lymphadenopathy, and rash. Desquamation of the distal extremities was observed some days later. Aneurysms were detected, involving the left and right main coronary arteries, as well as the left anterior descending coronary. Magnetic resonance angiography of the chest and abdomen revealed no other involved vessels. The child again received IVIG, pulse methylprednisolone, and infliximab,

\footnotetext{
* Correspondence: pcr.patricia@gmail.com

${ }^{1}$ Department of Pediatrics, Santa Maria Hospital, Lisbon, Portugal
}

Full list of author information is available at the end of the article but remained febrile and developed significant arthritis, requiring daily prednisolone. He is now asymptomatic.

\section{Conclusions}

Currently, recurrent and refractory Kawasaki disease still represents a therapeutic challenge.

\section{Author details}

${ }^{1}$ Department of Pediatrics, Santa Maria Hospital, Lisbon, Portugal. ²Division of Rheumatology, Morgan Stanley Children's Hospital of New York-Presbyterian, Columbia University Medical Center (MSCHONY/CUMC), New York, USA.

Published: 14 September 2011

doi:10.1186/1546-0096-9-S1-P98

Cite this article as: Costa Reis et al:: Recurrent refractory Kawasaki disease. Pediatric Rheumatology 2011 9(Suppl 1):P98.
Submit your next manuscript to BioMed Central and take full advantage of:

- Convenient online submission

- Thorough peer review

- No space constraints or color figure charges

- Immediate publication on acceptance

- Inclusion in PubMed, CAS, Scopus and Google Scholar

- Research which is freely available for redistribution

Submit your manuscript at www.biomedcentral.com/submit
C Biomed Central
C Biomed Central

두 2011 Costa Reis et al; licensee BioMed Central Ltd. This is an open access article distributed under the terms of the Creative Commons Attribution License (http://creativecommons.org/licenses/by/2.0), which permits unrestricted use, distribution, and reproduction in any medium, provided the original work is properly cited. 